\title{
HOLOCENE BOND CYCLES: REAL OR IMAGINARY?
}

H. W a nner, J. B ütik ofer: Holocene Bond Cycles: real or imaginary? - Geografie-Sborník ČGS, 113, 4, pp. 338-350 (2008). - During the Holocene (last 12,000 years) nine cold relapses were observed mainly in the North Atlantic Ocean area and its surroundings. Based on the pioneering studies by Bond et al. $(1997,2001)$ these events are called Bond Cycles and thought to be the Holocene equivalents of the Pleistocene Dansgaard-Oeschger cycles. The first event was the Younger Dryas ( 12,000 BP; Broecker 2006 ), the last one was the Little Ice Age (AD 1350-1860; Grove 1988). A number of trigger mechanisms is discussed (see Table 1), but a theory for the Bond Cycles does not exist. Based on spectral analyses of both, forcing factors and climatological time series, we argue that one single process did likely not cause the Holocene cooling events. It is conceivable that the early Holocene coolings were triggered by meltwater pulses. However, the late Holocene events (e.g., the Little Ice Age) were rather caused by a combination of different trigger mechanisms. In every case it has to be taken in mind that natural variability was also playing a decisive role.

KEY WORDS: Holocene - Bond Cycles - spectral analysis - triggering processes - Little Ice Age

\section{Introduction}

The Holocene epoch, commonly considered as the recent interglacial, has sustained the growth and development of modern society. Nevertheless, the knowledge about global climate variability during this period is surprisingly sparse (Mayewski et al. 2004, Wanner et al. 2008). The Holocene climate can be considered in three main phases or time periods (Nesje and Dahl 1993, Marchal et al. 2002). The first includes the Preboreal and Boreal chronozones and lasted from about 11.6 to $9 \mathrm{kyr}$ BP. The second phase, the Hypsithermal, which includes the relatively warm Atlantic chronozone, covers the period between about 9 and circa $5.7 \mathrm{kyr}$ BP. In earlier papers it is also called "Altithermal" or "Holocene climate optimum". The third phase, including the Subboreal and Subatlantic chronozones, lasted from 5.7 to $0 \mathrm{kyr}$ BP, and is called Neoglacial because it is characterized by several cold relapses with remarkable glacier advances in different areas of the globe. In their pioneering overview Denton and Karlén (1973) showed that the whole Holocene experienced alternating intervals of glacier advances (600-900 yr in duration) and retreats (lasting up to $1750 \mathrm{yr}$ ) but, according to their studies, the strongest advances occurred during the Neoglacial around 200-350, 2800 and 5300 cal yr BP (calendar years before present). The authors concluded that the solar activity was a possible trigger for these fluctuations. Observations in the northern (e.g. Dansgaard et al. 1993) and southern midto high-latitudes indicate that the climate during the Holocene was rather stationary. In contrast, proxy based reconstructions show that strong 

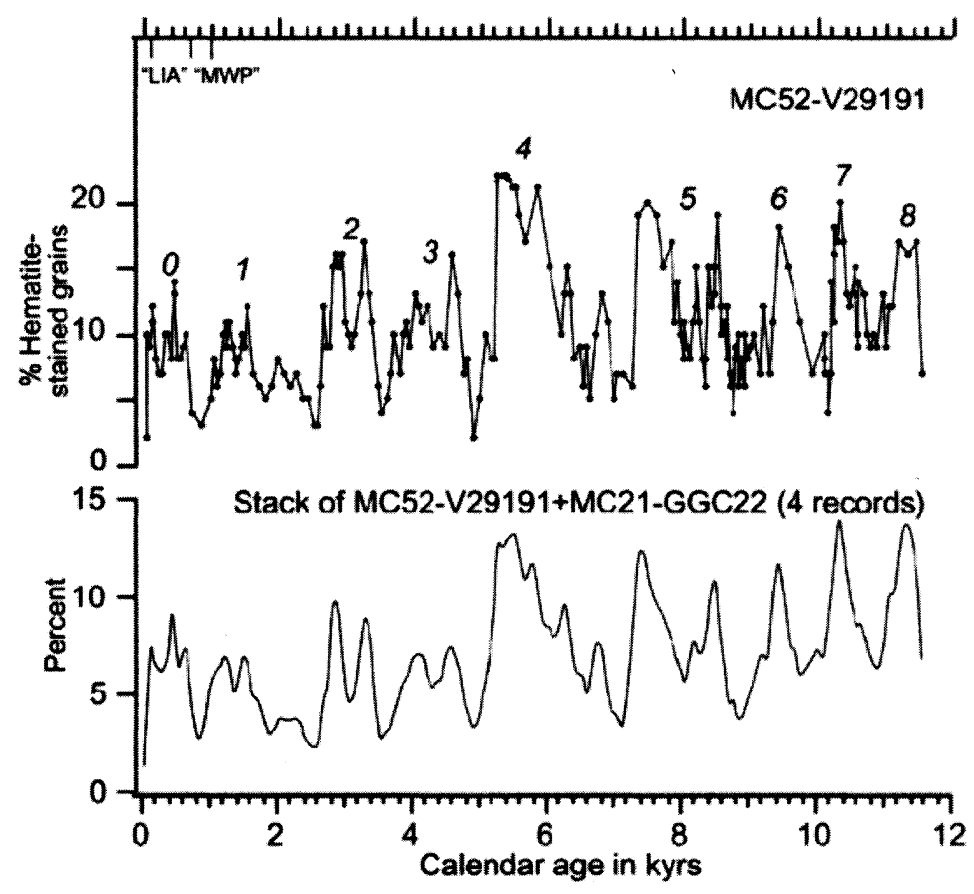

Fig. 1 - Holocene records of drift-ice as percentage variations in petrologic tracers. Upper panel: Hematite stained grains in $\%$ in two cores from the same location. Lower panel: Stack of four records at different locations. Bond et al. 1999, modified.

hydrological or circulation changes took place in the tropics and subtropics (Gasse 2000).

A larger progress in the understanding of Holocene climate variability was made by combining specific proxy data and climate models. One of the important insights of the COHMAP (Cooperative Holocene Mapping Project) was that the orbitally induced increase in solar insolation in summer between 12,000 and 6,000 cal years BP enhanced the thermal contrast between land and sea, and thus induced stronger summer monsoons generating a more humid climate in subtropical Africa as well as in west and central Asia (COHMAP Members 1988, Wright et al. 1993). These results were confirmed by the recent simulations of PMIP, the Paleoclimate Modeling Intercomparison Project (Braconnot et al. 2007).

Mainly triggered by the early studies of Denton and Karlén (1973) as well as the debate about the transition from the Medieval Warm Period (MWP) or Epoch to the Little Ice Age (LIA), several studies concentrated on the question whether the centuries or even millennia long climate variations during the Holocene were cyclic or not (O'Brien et al. 1995). The discussion was strongly stimulated by the investigations of Bond et al. (1997, 2001) who, mainly based on petrologic tracers of drift-ice in the North Atlantic (NA), postulated a "1500 year" cycle that is supposed to have persisted throughout the Holocene. These cycles were thought to be the Holocene 
Table 1 - Schematic overview on 28 papers discussing the phenomenon of the Bond Cycles (Abbreviations: AO Arctic Oscillation, IOM Indian Ocean Mosoon, IRD Ice Rafted Debris, ISOW Iceland-Scotland Overflow Water, ITCZ Intertropical Convergence Zone, MOC Meridional Overturning Circulation, NADW North Atlantic Deep Water, NAO North Atlantic Oscillation, ODP Ocean Drilling Program, SST Sea Surface Temperature, THC Thermohaline Circulation).

\begin{tabular}{|c|c|c|c|c|c|}
\hline Reference & Location & $\begin{array}{l}\text { Data } \\
\text { source(s)/parameters }\end{array}$ & $\begin{array}{l}\text { Correlation with } \\
\text { bond cycle(s) }\end{array}$ & $\begin{array}{l}\text { Reported spectral } \\
\text { peaks/length of cycle(s) }\end{array}$ & Possible mechanism \\
\hline $\begin{array}{l}\text { O'Brien et al. } \\
1995\end{array}$ & $\begin{array}{l}\text { Greenland } \\
\text { (GISP2) }\end{array}$ & $\begin{array}{l}\text { Sea salt, terrestrial } \\
\text { dust from ice core }\end{array}$ & $\begin{array}{l}\text { Yes (with cycles } \\
0,2,4,5,8)\end{array}$ & Quasi 2600-year cycles & $\begin{array}{l}\text { Enhanced meridional circulation } \\
\text { (atmosphere) }\end{array}$ \\
\hline $\begin{array}{l}\text { Bianchi and } \\
\text { McCave } 1999\end{array}$ & $\begin{array}{l}\text { South } \\
\text { Iceland } \\
\text { basin }\end{array}$ & $\begin{array}{l}\text { Sortable silt mean } \\
\text { size }\end{array}$ & $\begin{array}{l}\text { Yes (with } \\
\text { cycles 0-6) }\end{array}$ & 1500-year periodicity & Changes in deep-water flow \\
\hline $\begin{array}{l}\text { Chapman and } \\
\text { Shackleton } \\
2000\end{array}$ & $\begin{array}{l}\text { North } \\
\text { Atlantic } \\
\text { off Iceland }\end{array}$ & $\begin{array}{l}\text { Ocean sediment core } \\
\text { (lightness, }{ }^{13} \mathrm{C} \text {, } \\
\mathrm{CaCO}_{3} \text { content) } \\
\end{array}$ & $\begin{array}{l}\text { Yes (with } \\
\text { cycles } 2,5,6,7 \text { ) }\end{array}$ & $\begin{array}{l}\text { Several spectral peaks } \\
\text { (e.g. } 1650,1000, \\
550 \text { years) }\end{array}$ & $\begin{array}{l}\text { Cycles possibly driven by variation in solar } \\
\text { activity (with consequences for THC } \\
\text { fluctuations) }\end{array}$ \\
\hline $\begin{array}{l}\text { de Menocal } \\
\text { et al. } 2000\end{array}$ & \begin{tabular}{|l|} 
Off Cap \\
Blanc, \\
Mauretania
\end{tabular} & $\begin{array}{l}\text { Ocean sediment core } \\
\text { (SST, } \delta^{18} \mathrm{O} \text {, terrigenous } \\
\text { (eolian) fraction) }\end{array}$ & $\begin{array}{l}\text { Yes (with cycles } \\
0-5,7,8)\end{array}$ & $\begin{array}{l}\text { About every } 1500 \pm 500 \\
\text { years }\end{array}$ & $\begin{array}{l}\text { Increased southward advection of cooler } \\
\text { waters or enhanced regional upwelling }\end{array}$ \\
\hline $\begin{array}{l}\text { Jennings } \\
\text { et al. } 2002\end{array}$ & \begin{tabular}{|l|} 
East \\
Greenland \\
Shelf
\end{tabular} & $\begin{array}{l}\text { Ocean sediment cores } \\
\text { (magnetic susceptibility, } \\
\delta^{18} \mathrm{O}, \mathrm{IRD}, \text { carbonate } \\
\text { flux) } \\
\end{array}$ & $\begin{array}{l}\text { Yes (with cycles } \\
1,2,3,5)\end{array}$ & - & $\begin{array}{l}\text { Increased flux of polar water and sea ice } \\
\text { (changing NAO indices?) }\end{array}$ \\
\hline $\begin{array}{l}\text { Fleitmann } \\
\text { et al. } 2003\end{array}$ & $\begin{array}{l}\text { Southern } \\
\text { Oman }\end{array}$ & Stalagmite $\left(\delta^{18} \mathrm{O}\right)$ & $\begin{array}{l}\text { Yes (with cycles } \\
2-6)\end{array}$ & Several shorter cycles & $\begin{array}{l}\text { IOM monsoon precipitation responds to Bond } \\
\text { events and to solar activity }\end{array}$ \\
\hline $\begin{array}{l}\text { Gupta et al. } \\
2003\end{array}$ & $\begin{array}{l}\text { Arabian } \\
\text { Sea }\end{array}$ & \begin{tabular}{|l|}
$\begin{array}{l}\text { G. bulloides shells } \\
\text { (southwest monsoon) }\end{array}$ \\
\end{tabular} & $\begin{array}{l}\text { Yes (with cycles } \\
1,3,4,6,7 \text { ) } \\
\end{array}$ & - & $\begin{array}{l}\text { Bond events and weak Asian southwest } \\
\text { monsoon (related to solar activity?) }\end{array}$ \\
\hline $\begin{array}{l}\text { Hong et al. } \\
2003\end{array}$ & $\begin{array}{l}\text { Tibetan } \\
\text { Plateau }\end{array}$ & $\begin{array}{l}\text { Peat bog }\left(\delta^{13} \mathrm{C} \text { values }\right. \\
\text { in cellulose of } 12 \\
\text { dominant plants })\end{array}$ & $\begin{array}{l}\text { Yes (with cycles } \\
1,3,5,7,8)\end{array}$ & - & $\begin{array}{l}\text { Thermohaline circulation decreases, SSTs } \\
\text { decrease in the North Atlantic and increase } \\
\text { in the Indian Ocean, monsoon weakens }\end{array}$ \\
\hline Hu et al. 2003 & \begin{tabular}{|l|} 
Arolik Lake \\
(south- \\
western \\
Alaska) \\
\end{tabular} & $\begin{array}{l}\text { Lake sediment }(\mathrm{BSi}, \\
\mathrm{OC}, \mathrm{ON}, \text { pollen, } \\
\left.\delta^{18} \mathrm{OSi}, \delta \mathrm{D}_{\mathrm{PA}}\right)\end{array}$ & $\begin{array}{l}\text { Yes (with cycles } \\
3,4,6,7,8)\end{array}$ & $\begin{array}{l}\text { Several spectral peaks } \\
\text { (e.g. } 590,950 \text { years })\end{array}$ & Possible sun-ocean-climate link \\
\hline $\begin{array}{l}\text { Niggemann } \\
\text { et al. } 2003\end{array}$ & $\begin{array}{l}\text { Sauerland } \\
\text { (Germany) }\end{array}$ & $\begin{array}{l}\text { Calcitic stalagmite } \\
\left(\delta^{18} \mathrm{O} \text {; indicator for }\right. \\
\text { paleohumidity })\end{array}$ & $\begin{array}{l}\text { Yes (mainly cycles } \\
1 \text { and } 2 \text { ) }\end{array}$ & $\begin{array}{l}1450 \text { years and minor } \\
\text { peaks }\end{array}$ & $\begin{array}{l}\text { Lower solar activity was probably } \\
\text { accompanied by drier climate in Northern } \\
\text { Europe }\end{array}$ \\
\hline $\begin{array}{l}\text { Oppo et al. } \\
2003\end{array}$ & $\begin{array}{l}\text { Northeastern } \\
\text { Atlantic } \\
\text { Ocean }\end{array}$ & $\begin{array}{l}\text { Benthic foraminifera } \\
\left(\delta^{18} \mathrm{O}, \delta^{13} \mathrm{C}\right)\end{array}$ & $\begin{array}{l}\text { Yes (with cycles } \\
2,4,5,6)\end{array}$ & $\begin{array}{l}\text { Millennial oscillation } \\
\text { of } \delta^{13} \mathrm{C}\end{array}$ & Enhanced and reduced NADW contribution \\
\hline $\begin{array}{l}\text { Risebrobakken } \\
\text { et al. } 2003\end{array}$ & \begin{tabular}{|l|} 
Eastern \\
Norwegian \\
Sea
\end{tabular} & $\begin{array}{l}\text { Ocean sediment cores } \\
\left({ }^{14} \mathrm{C}, \delta^{18} \mathrm{O}\right)\end{array}$ & $\begin{array}{l}\text { Yes (with cycles } \\
0,2,4,6,7)\end{array}$ & $\begin{array}{l}\text { No evidence for a clear } \\
\text { cyclic behaviour, weak } \\
\text { evidence for an } 81 \text {-year } \\
\text { cycle }\end{array}$ & $\begin{array}{l}\text { Stronger westerlies during early to } \\
\text { mid-Holocene gave rise to an eastward } \\
\text { migration of subsurface Arctic water, no } \\
\text { response to solar activity }\end{array}$ \\
\hline Yu et al. 2003 & \begin{tabular}{l|} 
Continental \\
western \\
Canada \\
\end{tabular} & $\begin{array}{l}\text { Fen peat record } \\
\text { (ash-free bulk density; } \\
\text { indicates moisture) }\end{array}$ & $\begin{array}{l}\text { Yes (with cycles } \\
0-5)\end{array}$ & $\begin{array}{l}\text { Broad band (mean: } \\
1785 \text { years) }\end{array}$ & $\begin{array}{l}\text { Wet periods correlate with warm periods in } \\
\text { the North Atlantic (response to solar } \\
\text { activity?) }\end{array}$ \\
\hline $\begin{array}{l}\text { Hall et al. } \\
2004\end{array}$ & \begin{tabular}{|l|} 
Subpolar \\
North \\
Atlantic
\end{tabular} & $\begin{array}{l}\text { Two ocean sediment } \\
\text { cores (silt mean size, } \\
\delta^{13} \mathrm{C} \text { ) }\end{array}$ & $\begin{array}{l}\text { Yes (with cycles } \\
0-3,5,6)\end{array}$ & $\begin{array}{l}\text { Broad band of } \\
\text { quasiperiodic } \\
\text { variability }\end{array}$ & $\begin{array}{l}\text { Link between the ISOW and the surface } \\
\text { component of the MOC }\end{array}$ \\
\hline $\begin{array}{l}\text { Baker et al. } \\
2005\end{array}$ & $\begin{array}{l}\text { Lake } \\
\text { Titicaca } \\
\text { (South } \\
\text { America) }\end{array}$ & $\begin{array}{l}\text { Sedimentary organic } \\
\text { matter }\left(\delta^{13} \mathrm{C} \text {; humidity }\right. \\
\text { and lake level })\end{array}$ & $\begin{array}{l}\text { Yes (with cycles } \\
1,2,4,5)\end{array}$ & $\begin{array}{l}\text { Several spectral peaks } \\
\text { (e.g. } 434-454 \text { years) }\end{array}$ & $\begin{array}{l}\text { Wet conditions on the Altiplano appear to be } \\
\text { associated with cold conditions (Bond events) } \\
\text { in the North Atlantic }\end{array}$ \\
\hline $\begin{array}{l}\text { Russell and } \\
\text { Johnson } 2005\end{array}$ & $\begin{array}{l}\text { Lake } \\
\text { Edward } \\
\text { (Uganda/ } \\
\text { Congo) }\end{array}$ & $\begin{array}{l}\text { Sediment cores } \\
(\% \mathrm{Mg}, \mathrm{Mg} / \mathrm{Ca})\end{array}$ & $\begin{array}{l}\text { Yes (with cycles } \\
0,1)\end{array}$ & $\begin{array}{l}\text { Enhanced power } \\
\text { at } \sim 725 \text { years }\end{array}$ & $\begin{array}{l}\text { Droughts in equatorial Africa occur during } \\
\text { both, cold and warm events in the North } \\
\text { Atlantic area, due to N-/S-displacement of } \\
\text { the ITCZ }\end{array}$ \\
\hline $\begin{array}{l}\text { Gupta et al. } \\
2005\end{array}$ & \begin{tabular}{|l|} 
North- \\
western \\
Arabian Sea
\end{tabular} & $\begin{array}{l}\text { ODP core } \\
\text { (\% of G. bulloides) }\end{array}$ & $\begin{array}{l}\text { Yes (with cycles } \\
0-7 \text { ) }\end{array}$ & $\begin{array}{l}\text { Several significant } \\
\text { peaks (e.g. at } 1550 \\
152,114,83 \text { years) }\end{array}$ & $\begin{array}{l}\text { Monsoon minima coincide with low sunspot } \\
\text { numbers and increased advection of drift ice } \\
\text { in the North Atlantic }\end{array}$ \\
\hline $\begin{array}{l}\text { Turney et al. } \\
2005\end{array}$ & $\begin{array}{l}\text { Northern } \\
\text { Ireland }\end{array}$ & $\begin{array}{l}>750 \text { oak tree ring } \\
\text { chronologies from bog } \\
\text { and lake sites }\end{array}$ & $\begin{array}{l}\text { Yes (with cycles } \\
0,2,4,5)\end{array}$ & $\begin{array}{l}\text { Broad band of } \\
\text { variability, dominant } \\
\text { cyclicity of } \sim 800 \text { years }\end{array}$ & $\begin{array}{l}\text { Trees collapse due to dryness during Bond } \\
\text { events, but no responses to changes in solar } \\
\text { activity }\end{array}$ \\
\hline
\end{tabular}




\begin{tabular}{|c|c|c|c|c|c|}
\hline Reference & Location & $\begin{array}{l}\text { Data } \\
\text { source(s)/parameters }\end{array}$ & $\begin{array}{l}\text { Correlation with } \\
\text { bond cycle(s) }\end{array}$ & $\begin{array}{l}\text { Reported spectral } \\
\text { peaks/length of cycle(s) }\end{array}$ & Possible mechanism \\
\hline $\begin{array}{l}\text { Wang et al. } \\
2005\end{array}$ & \begin{tabular}{|l|} 
Dongge \\
Cave \\
(southern \\
China) \\
\end{tabular} & $\begin{array}{l}\text { Stalagmite }\left(\delta^{18} \mathrm{O}:\right. \\
\text { monsoon } \\
\text { precipitation })\end{array}$ & $\begin{array}{l}\text { Yes (with cycles } \\
0-5)\end{array}$ & $\begin{array}{l}1 \text { to } 5 \text { centuries long, } \\
\text { peaks at } 159 \text { and } 206 \\
\text { years }\end{array}$ & $\begin{array}{l}\text { Correlation with ice rafted debris in North } \\
\text { Atlantic (influence of solar activity?) }\end{array}$ \\
\hline $\begin{array}{l}\text { Willard et al. } \\
2005\end{array}$ & \begin{tabular}{|l|} 
Chesapeake \\
Bay (E \\
North \\
America)
\end{tabular} & $\begin{array}{l}\text { Pollen from sediment } \\
\text { core (winter } \\
\text { temperature) }\end{array}$ & $\begin{array}{l}\text { Yes (mainly cycle } \\
1 \text { and } 5 \text { ) }\end{array}$ & $\begin{array}{l}1429,282,177,148 \\
\text { years }\end{array}$ & $\begin{array}{l}\text { Cold events in the North Atlantic are also } \\
\text { effective in E North America }\end{array}$ \\
\hline $\begin{array}{l}\text { Lamy et al. } \\
2006\end{array}$ & \begin{tabular}{|l|} 
Black Sea / \\
Gulf of \\
Aqaba
\end{tabular} & $\begin{array}{l}\text { Three sediment cores } \\
\text { inferring hydroclimatic } \\
\text { changes (clay layer } \\
\text { frequency, } \delta^{18} 0 \text {, } \\
\text { terrigenous sand } \\
\text { accumulation rate) }\end{array}$ & Partly & $\begin{array}{l}\text { Cycles of } \sim 800 \text { and } \\
\sim 500 \text { years }\end{array}$ & $\begin{array}{l}\text { AO/NAO-like atmospheric variability, likely } \\
\text { originating from solar output changes, plays } \\
\text { a dominating role for hydroclimatic changes } \\
\text { in the study area }\end{array}$ \\
\hline $\begin{array}{l}\text { Moros et al. } \\
2006\end{array}$ & $\begin{array}{l}\text { Area off } \\
\text { north } \\
\text { Iceland }\end{array}$ & $\begin{array}{l}\text { Phase analyses of } \\
\text { mineralogical quartz } \\
\text { and quartz/ plagioclase } \\
\text { ratio }\end{array}$ & Partly & $\begin{array}{l}1300 \text { years, } 75-80 \\
\text { years }\end{array}$ & $\begin{array}{l}\text { Late Holocene trend in drift ice: Increasing } \\
\text { in the cold East Greenland Current, } \\
\text { decreasing in warmer North Atlantic Drift }\end{array}$ \\
\hline $\begin{array}{l}\text { Viau et al. } \\
2006\end{array}$ & $\begin{array}{l}\text { North } \\
\text { America }\end{array}$ & $\begin{array}{l}752 \text { pollen records from } \\
\text { terrestrial sediments } \\
\text { (July temperature) }\end{array}$ & $\begin{array}{l}\text { Yes (with cycles } \\
0-2,5)\end{array}$ & $\begin{array}{l}\text { Periodicity of circa } 1150 \\
\text { years }\end{array}$ & Possibly solar forcing? \\
\hline $\begin{array}{l}\text { Yu, Y. et al. } \\
2006\end{array}$ & $\begin{array}{l}\text { Hexi } \\
\text { Corridor } \\
\text { (northwest } \\
\text { China) }\end{array}$ & $\begin{array}{l}\text { Lake sediment core, } \\
\text { loess-paleosol (MS, } \\
\left.\mathrm{CaCO}_{3}, \mathrm{GS}, \mathrm{SCR}\right)\end{array}$ & $\begin{array}{l}\text { Yes (with cycles } \\
0,2,5,7,8)\end{array}$ & - & $\begin{array}{l}\text { Southward expansion of northern polar } \\
\text { vortex (NAO-), El Niñ like patterns, strongly } \\
\text { weakened Asian summer monsoon }\end{array}$ \\
\hline $\begin{array}{l}\text { Allen et al. } \\
2007\end{array}$ & $\begin{array}{l}\text { Finnmark, } \\
\text { Norway }\end{array}$ & $\begin{array}{l}\text { Lake sediment cores } \\
\left({ }^{14} \mathrm{C} \text { ages, pollen, }\right. \\
\text { temperature and } \\
\text { humidity measures, } \\
\text { organic content) }\end{array}$ & $\begin{array}{l}\text { Yes (e.g. cycles } \\
0,1,5)\end{array}$ & $\begin{array}{l}\text { Several spectral peaks } \\
\text { (e.g. } 1808 / 09,1639 / 45 \\
1064,767,348-411 \\
279-312,188 \text { years) }\end{array}$ & $\begin{array}{l}\text { Complex interaction between oceanic and } \\
\text { atmospheric circulation, solar and tidal } \\
\text { variability }\end{array}$ \\
\hline $\begin{array}{l}\text { Bendle, } \\
\text { Rosell-Melé } \\
2007 \\
\end{array}$ & $\begin{array}{l}\text { North } \\
\text { Icelandic } \\
\text { Shelf }\end{array}$ & $\begin{array}{l}\text { Alkenone indices } \\
\text { (SST) }\end{array}$ & $\begin{array}{l}\text { Yes (with cycles } \\
0,2 \text { ) }\end{array}$ & - & $\begin{array}{l}\text { No close correlation with Bond Cycles, rather } \\
\text { with NAO dynamics }\end{array}$ \\
\hline Li et al. 2007 & \begin{tabular}{|l|} 
White Lake \\
(NE USA)
\end{tabular} & \begin{tabular}{|l|} 
Two cores $\left({ }^{14} \mathrm{C}\right.$, \\
terrestrial macrofossils)
\end{tabular} & $\begin{array}{l}\text { Yes (with cycles } \\
1-4)\end{array}$ & - & $\begin{array}{l}\text { Dry intervals correlate with cold periods in } \\
\text { the North Atlantic Ocean }\end{array}$ \\
\hline $\begin{array}{l}\text { Mangini et al. } \\
2007\end{array}$ & $\begin{array}{l}\text { Spannagel } \\
\text { Cave } \\
\text { (central } \\
\text { European } \\
\text { Alps) }\end{array}$ & $\begin{array}{l}\text { Stalagmites } \\
\left(\delta^{18} 0: \text { winter }\right. \\
\text { precipitation })\end{array}$ & $\begin{array}{l}\text { Yes (with cycles } \\
0,2,3,4,5)\end{array}$ & - & $\begin{array}{l}\text { Meteorological conditions in the European } \\
\text { Alps respond synchronously to } \\
\text { hydrographical changes in the North } \\
\text { Atlantic }\end{array}$ \\
\hline
\end{tabular}

equivalents of the Pleistocene Dansgaard-Oeschger cycles (Alley 2005). The upper panel of Figure 1 shows the timeseries of hematite-stained grains (HSG) in form of a tied record from the MC-52 and VM29-191 cores from the same location (Bond et al. 2001). The lower panel shows a stack of four records from different locations in the North Atlantic area. The mechanistic explanation for the cyclic behaviour of these time series is that the high peaks with fresh volcanic glass from Iceland or Jan Mayen and HSG's from eastern Greenland are the result of the southward and eastward advection of cold, ice-bearing surface waters from the Nordic and Labrador Seas during cold periods (Bond et al. 1997). Bond et al. (2001) detected totally nine cold events during the Holocene, which were also interpreted as a consequence of a periodic expansion of the cold polar anticyclone and an enhanced meridional circulation (O'Brien et al 1995). The Bond Cycles are numbered from 0 to 8 (Fig. 1). They peaked around 400, 1,400, 2,800, 4,300, 5,900, $8,100,9,400,10,300$ and 11,100 cal years BP. The shift from the MWP to the cold LIA with high HSG values is clearly visible in Figure 1 (upper panel). In the following we want to answer three questions:

- Where are Bond Cycles postulated in paleoclimate records? 
- Do proxy time series show a similar spectral (cyclic) behaviour, and are the cycles synchronous?

- What are the possible processes causing Bond Cycles during the Holocene?

\section{Where are Bond Cycles postulated in paleoclimate records?}

The existence of Bond Cycles is reported for many areas of the globe (Bütikofer 2007). Table 1 shows a list of 28 scientific papers which refer to Bond Cycles. The series of papers starts with the publication of O'Brien et al. (1995), which was the main trigger for the deep sea research launched by the late Gerard Bond and his colleagues (Bond et al. 1997, 2001), and ends with several very recent papers. Not only the character of the data sources (e.g. isotopes or organic and anorganic compounds detected in ice cores, lake or ocean sediment cores, stalagmites, records from peat bogs) but also their spatial variety is considerable. With the exception of the Pacific area, Australia and Antarctica, multi-century to millennial scale ("Bond like") climate cycles in proxy data sets of almost all areas of the globe are interpreted to be associated with the Bond Cycle phenomenon. Yet, it is no surprise that the highest number was detected in the North Atlantic Ocean and its surroundings, followed by several studies from Arabia and Asia.

\section{Do proxy time series show a similar spectral (cyclic) behaviour, and are the cycles synchronous?}

The original data (Fig. 1) show that the cycles based on the HSG analysis by Bond et al. (1997) were quite regular during the Holocene, with a mean pacing of $\sim 1500$ years. Table 1 shows that correlations are reported between the proxy time series and all of the nine Holocene Bond Cycles. The mostly mentioned correlations with Bond Cycles in the 28 papers according to Table 1 are cycle $2(\sim 2800$ years BP) and cycle $5(\sim 8100$ years BP). In order to answer the question about the spectral behaviour and the synchroneity of the observed cycles, Figure 2 shows the significant (90\% level) spectral peaks as described in the vast literature (black dots) and as determined by our time series analyses (open circles; Bütikofer 2007). The different dots and circles are plotted against the corresponding latitude of each record. No clear clustering is visible at all. The majority of the analyses is concentrated in the latitudes between the southern subtropics and the north pole. If we concentrate on the spectral peaks around 1500 years we recognize several dots/circles which are concentrated between 35 and $62^{\circ} \mathrm{N}$. These are all located in the North Atlantic area.

Figure 3 shows the frequency distribution of all spectral peaks represented in Figure 2. As expected, the number of spectral peaks grows with decreasing timescale because the number of existing long proxy time series is limited. Small, (and non-significant) clusterings of spectral peaks occur at about 200, 500, 900 and 1500 years (dark bars in Fig. 3). 


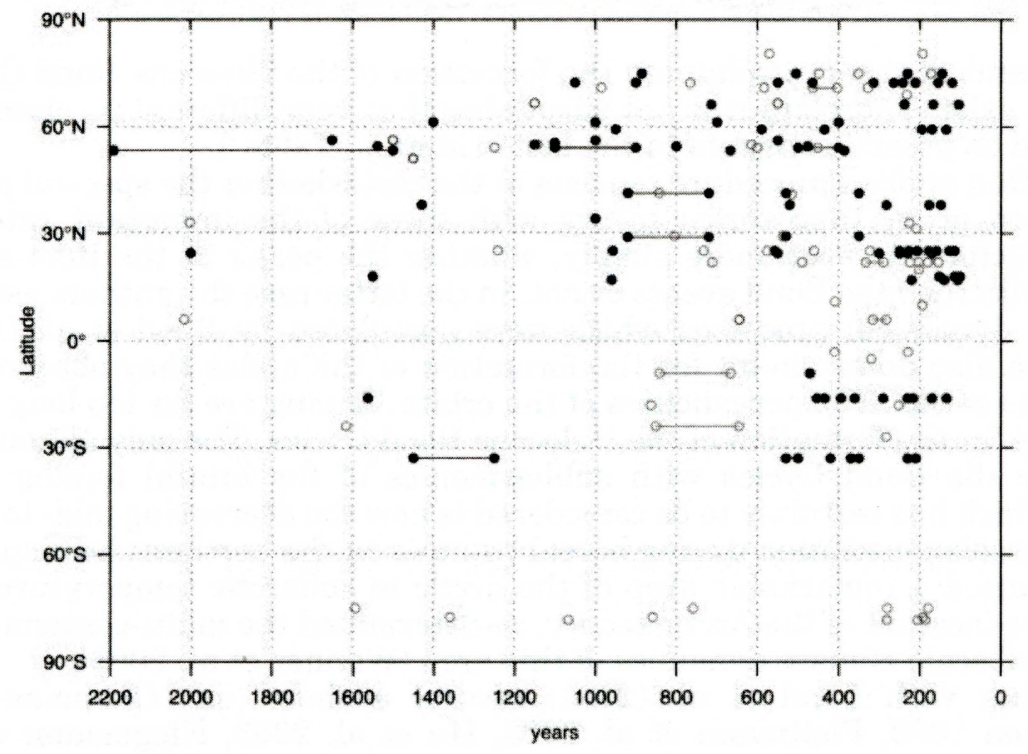

Fig. 2 - Overview of the spectral behaviour of the time series analysed by Bütikofer (2007; open circles) or of a number of referenced spectral peaks in the literature (referenced in Wanner et al. 2008; black dots). Horizontal lines represent broad peaks. The x-axes represents the times scales of the different peaks, the y-axes shows the corresponding latitude of the proxy.

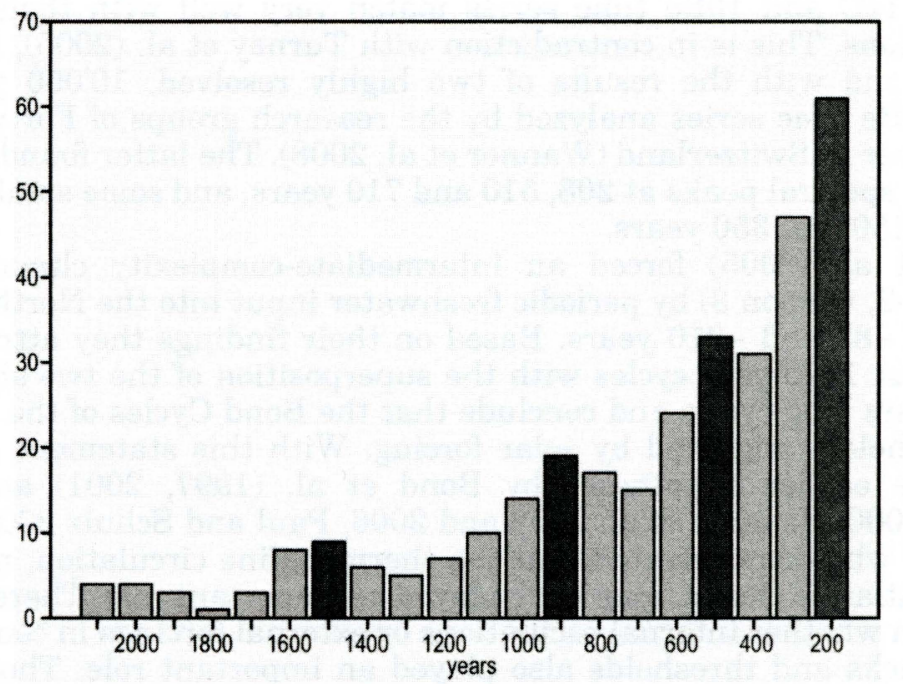

Fig. 3 - Number of all significant spectral peaks found in the timeseries represented in Figure 2. Dark grey bars mark apparently, but not significant higher frequencies. 


\section{What are the possible processes causing the Bond Cycles?}

A dynamical theory explaining the formation of the Holocene Bond Cycles does not exist. Therefore it is not surprising that very different mechanisms are listed as possible triggers in the last column of Table 1.

One often applied procedure consists in the test whether the spectral peaks of selected proxy time series covary with those of the important external forcing factors or, even more simply, whether the peaks in the time series covary with the nine Bond events or not. In the latter case the authors assume that the dynamical processes which were postulated by Bond et al. (1997, 2001) are also determinant for the formation of the cycles they observed in their time series. The periodicities of the orbital forcing are far too long to be the cause for the formation of the Holocene Bond Cycles. The only option is to associate the Bond Cycles with subharmonics of the orbital forcing. One aspect which has certainly to be considered is how the decreasing mid- to lateHolocene solar insolation during boreal summer in the northern hemisphere, which caused a remarkable drop of the arctic to subarctic temperature and a massive increase of the Arctic sea ice, co-determined the multi-centennial to millennial scale climate dynamics of this area (Wanner et al. 2008).

Together with Bond et al. (2001) several authors (e.g. Chapman and Shackleton 2000, Fleitmann et al. 2003, Hu et al. 2003, Niggemann et al. 2003, Yu. et al. 2003, Gupta et al. 2005, Wang et al. 2005, Lamy et al. 2006, Viau et al. 2006, Allen et al. 2007) considered that solar forcing was the determining or at least one determining factor of their reconstructed multicentury to millennial scale climate fluctuations. Bond et al. (2001) linked their drift-ice records with the production rate of the two nuclides $14 \mathrm{C}$ and $10 \mathrm{Be}$ in Greenland ice cores. Both nuclides are related to solar wind and solar activity (or solar irradiance) in the sense that higher production rates are associated with a reduced solar irradiance. Bond et al. (2001) show that the Greenland $14 \mathrm{C}$ and $10 \mathrm{Be}$ time series match very well with their drift-ice reconstructions. This is in contradiction with Turney et al. (2005), Debret et al. (2007), and with the results of two highly resolved, 10'000 year long $14 \mathrm{C}$ and $10 \mathrm{Be}$ time series analyzed by the research groups of Fortunat Joos and Jürg Beer in Switzerland (Wanner et al. 2008). The latter found the most remarkable spectral peaks at 208, 510 and 710 years, and some smaller peaks at $87,104,150$ and 350 years.

Braun et al. (2005) forced an intermediate-complexity climate model (CLIMBER-2, version 3) by periodic freshwater input into the North Atlantic in cycles of $\sim 87$ and $\sim 210$ years. Based on their findings they attribute the rather robust 1470 year cycles with the superposition of the two shorter, 87 and 210 years long cycles and conclude that the Bond Cycles of the Holocene were nonetheless triggered by solar forcing. With this statement they also support the earlier hypotheses by Bond et al. $(1997,2001)$ and others (Broecker 2000, Renssen et al. 2002 and 2006, Paul and Schulz 2002, Schulz et al. 2007) who demonstrated that the thermohaline circulation, namely in the North Atlantic Ocean, may have played an important role. There remains the question whether internal oscillations or external forcings in combination with feedbacks and thresholds also played an important role. Though Paul and Schulz (2002) state that internal oscillations of the meridional circulation do not rely on any external forcing, or they can draw energy of it.

There is clear evidence that the thermohaline circulation interacts with the Arctic sea ice. Bennike (2004) reports that, in northwest Greenland, surface 
waters were warmer and less sea ice than at present existed from 7300 to 3700 cal yr BP. That means the sea ice started to grow after this period. In their run with the ECBilt-CLIO-VECODE model Renssen et al. (2006) showed that negative total solar irradiance (TSI) anomalies increase the probability of a local shutdown of deep convection in the Nordic Seas. This initial cooling associated with TSI reductions leads to sea-ice expansion in the area, which stratifies the water column and hampers deepwater formation.

Some authors (e.g. Briffa et al. 1998) argument that large volcanic eruptions can low summer temperatures dramatically. Robock (2000) and Fischer et al. (2006) demonstrated that one single tropical volcanic eruption leads to a climate signal which only lasts for about 2-3 years. Wanner et al. (2008) point to the fact that a higher number of large tropical volcanic eruptions has occurred during certain intervals of the last millennium, i.e. between $A D 1200$ and 1350 or around $A D 1700$ and 1800. During the last millennium these maxima of volcanic activity happened to coincide with both, low orbitally induced insolation in the Northern Hemisphere and an unusual concentration of solar activity minima (Wolf, Spörer, Maunder, Dalton) which likely led to the lowest temperatures in this area since 8000 years.

Other processes such as tidal forcing (Keeling, Whorf 1997; Berger, von Rad 2002), the influence of cosmic rays and the global electric circuit (Tinsley et al. 2007, Kirkby 2007) or changes in the Earth's magnetic field (Courtillot et al. 2007) are also hold responsible for decadal to multi-century long climate fluctuations. Finally, it has to be taken in mind that forcing signals with higher frequencies might also be transformed into low frequency ones by slow reactors such as ice caps, or by internal feedbacks. In addition, some authors even express their doubt about a direct forcing of the decadal to multi-century scale cooling events. Related to the Dansgaard-Oeschger events Ditlevsen et al. (2007) vote that a detection of periodicity relies strongly on the accuracy of the dating of these events, and Wunsch (2000) states that a broad band of quasiperiodic variability rather than any kind of significant spectral peak is typical for climate records.

\section{Conclusions}

We have demonstrated that evidence for the existence of nine 1500 years long cold or cool events during the Holocene, called Bond Cycles, exists at least in the North Atlantic area and its surroundings (Fig. 1) where such cycles were described by different authors (Table 1). A theory explaining the formation of these cycles does not exist. This fact is reflected in the long list of possible mechanisms which can trigger Bond events (Table 1). Therefore, the scepticism of different authors voting that one single factor may not be responsible for the cold relapses during the Holocene (e.g., Schulz and Paul 2002, Moros et al. 2006, Ditlevsen et al. 2007) is justyfiable. Their reservations are further supported by the fact that the natural (external) forcing factors changed remarkably during the Holocene (Wanner et al. 2008). First of all, the orbitally induced summer insolation decreased strongly between $10 \mathrm{kyr} \mathrm{BP}$ and the present. This led to decreasing temperatures in the North Atlantic Ocean as well as in the northern continental areas of the Northern Hemisphere which favoured the growth of the Arctic sea ice and the strengthening of the cold polar surface anticyclone. These processes were possibly amplified during periods with a low solar activity and an 


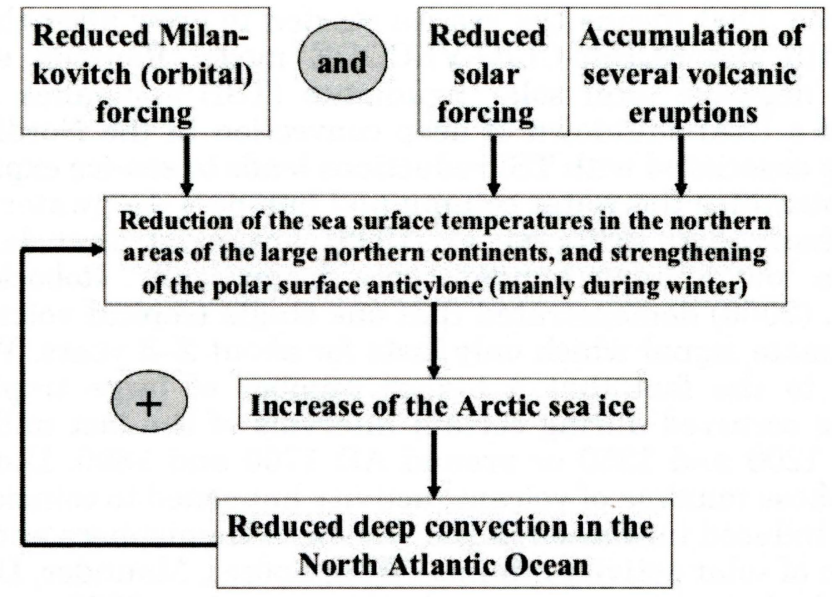

Fig. 4 - Possible mechanism for the formation of a cold event during the late Holocene (e.g., the Little Ice Age) when the summer orbtital forcing in the northern hemisphere coincided with a low solar activity and accumulations of strong volcanic.

accumulation of strong, climate-relevant volcanic eruptions. This was likely the case during the period of the Neoglacial (Denton and Karlén 1973), above all during the Little Ice Age (Wanner et al. 2008).

In form of a simplified scheme Figure 4 tries to represent a possible mechanism for the formation of a cold Holocene event. If we assume that the summer orbital insolation in the Northern Hemisphere was much stronger in the early Holocene (Wanner et al. 2008) and that the Arctic sea ice was very sparse (Bennike 2004), it is indicated that cold relapses such as the $8.2 \mathrm{kyr}$ event were likely triggered by strong meltwater pulses (Barber et al. 1999, Renssen et al. 2002). The late Holocene cold events (Bond events 0, 1 and 2 in Fig. 1) were rather caused by mechanisms which are shown in Figure 4 . We are fully aware that this conclusion is still speculative and must be investigated with further data analyses as well as suitable model runs.

\section{References:}

ALLEN, J. R. M., LONG, A. J., OTTLEY, C. J., PEARSON, D. G., HUNTLEY, B. (2007): Holocene climate variability in northernmost Europe. Quaternary Science Reviews, 26, pp. 1432-1453.

ALLEY, R. B. (2005): Abrupt climate changes, oceans, ice, and us. Oceanography, 17, pp. 194-204.

BAKER, P. A., FRITZ, S. C., GARLAND, J., EKDAHL, E. (2005): Holocene hydrologic variation at Lake Titicaca, Bolicia/Peru, and its relationship to North Atlantic climate variation. Journal of Quaternary Science, 20, pp. 655-662.

BARBER, D. C., DYKE, A., HILLAIRE-MARCEL, C., JENNINGS, A. E., ANDREWS, J. T., KERWIN, M. W., BILODEAU, G., McNEELY, R., SOUTHON, J., MOREHEAD, M. D., GAGNON, J.-M. (1999): Forcing of the cold event of 8,200 years ago by catastrophic drainage of Laurentide lakes. Nature, 400, pp. 344-348.

BENDLE, J. A. P., ROSELL-MELÉ, A. (2007): High-resolution alkenone sea surface temperature variability on the North Icelandic Shelf: implications for Nordic Seas 
palaeoclimate development during the Holocene. The Holocene, 17, pp. 9-24.

BENNIKE, O., (2004): Holocene sea-ice variations in Greenland: onshore evidence. The Holocene, 14, pp. 607-613.

BERGER, W. H., von RAD, U. (2002): Decadal to millennial cyclicity in varves and turbidites from the Arabian Sea: Hypothesis of tidal origin. Global and Planetary Change, 34, pp. 313-325.

BIANCHI, G. G., McCAVE, I. N. (1999): Holocene periodicity in North Atlantic climate and deep ocean flow south of Iceland. Nature, 397, pp. 515-517.

BOND, G., SHOWERS, W., CHESEBY, M., LOTTI, R., ALMASI, P., DE MENOCAL, P., PRIORE, P., CULLEN, H., HAJDAS, I., BONANI, G. (1997): A pervasive millennialscale cycle in the North Atlantic Holocene and glacial climates. Science, 294, pp. 2130-2136.

BOND, G., KROMER, B., BEER, J., MUSCHELER, R., EVANS, M. N., SHOWERS, W., HOFFMANN, S., LOTTI-BOND, R., HAJDAS, I., BONANI, G. (2001): Persistent solar influence on North Atlantic climate during the Holocene. Science, 278, pp. 1257-1266.

BRACONNOT, P., OTTO-BLIESNER, B., HARRISON, S., JOUSSAUME, S., PETERCHMITT, J.Y., ABE-OUCHI, A., CRUCIFIX, M., DRIESSCHAERT, E., FICHEFET, Th., HEWITT, C. D., KAGEYAMA, M., KITOH., A., LÂIMÉ, A., LOUTRE, M.-F., MARTI, O., MERKEL, U., RAMSTEIN, G., VALDES, P., WEBER, S.L., YU, Y., ZHAO, Y. (2007): Results of PMIP2 coupled simulations of the Mid-Holocene and Last Glacial Maximum - Part 1: experiments and large-scale features. Climate of the Past, 3, pp. 261-277.

BRAUN, H., CHRISTL, M., RAHMSTORF, S., GANOPOLSKI, A., MANGINI, A., KUBATZKI, C., ROTH, K., KROMER, B. (2005): Possible solar origin of the 1,470-year glacial climate cycle demonstrated in a coupled model. Nature, 438, pp. 208-211.

BRIFFA, K. R., JONES, P. D., SCHWEINGRUBER, F. H., OSBORN, T. J., (1998.): Influence of volcanic eruptions on Northern Hemisphere summer temperature over the past 600 years. Nature, 393, pp. $450-455$.

BROECKER, W. S. (2000): Was a change in thermohaline circulation responsible for the Little Ice Age? Proceedings of the National Academy of Sciences (USA), 97, pp. 1339-1342.

BROECKER, W. S. (2006). Was the Younger Dryas triggered by a flood? Science, 312, pp. 1146-1148.

BÜTIKOFER, J. (2007): Millennial scale climate variability during the last 6000 years - tracking down the Bond cycles. Diploma thesis. University of Bern, $124 \mathrm{p}$. (www.giub.unibe.ch/klimet/docs/diplom_jbuetikofer.pdf)

CHAPMAN, M. R., SHACKLETON, N. J. (2000): Evidence of 550-year and 1000-year cyclicities in North Atlantic circulation patterns during the Holocene. The Holocene, 10, pp. 287-291.

COHMAP Members (1988): Climatic changes of the last 18,000 years: Observations and model simulations. Science, 241, pp. 1043-1052.

COURTILLOT, V., GALLET, Y., LE MOUEL, J.-L., FLUTEAU, F., GENEVEY, A. (2007): Are there connections between the Earth's magnetic field and climate. Earth and Planetary Science Letters, 253, pp. 328-339.

DANSGAARD, W., JOHNSEN, S. J., CLAUSEN, H. B., DAHL-JENSEN, D., GUNDESTRUP, N. S., HAMMER, C. U., HVIDBERG, C. S., STEFFENSEN, J. P., SVEINSBJÖRNSDOTTIR, A. E., JOUZEL, J., BOND, G. (1993). Evidence for general instability of past climate from a 250-kyr ice-core record. Nature, 364, pp. 218-220.

DEBRET, M., BOUT-ROUMAZEILLES, V., GROUSSET, F., DESMET, M., McMANUS, J. F., MASSEI, N., D. SEBAG, D., PETIT, J.-R., COPARD, Y., TRENTESAUX, A. (2007) : The origin of the 1500-year climate cycles on Holocene North-Atlantic records. Climate of the Past, 3, pp. 679-692.

deMENOCAL, P., ORTIZ, J., GUILDERSON, T., SARNTHEIM, M. (2000): Coherent high and low latitude climate variability during the Holocene warm period. Science, 288, pp. 2198-2202.

DENTON, G. H., KARLÉN, W. (1973): Holocene climatic variations - Their pattern and possible cause. Quaternary Research, 3, pp. 155-205.

DITLEVSEN, P. D., ANDERSEN, K. K., SVENSSON, A. (2007): The DO-climate events are probably noise induced: statistical inverstigation of the claimed 1470 years cycle. Climate of the Past, 3, pp. 129-134.

FISCHER, E., LUTERBACHER, J., ZORITA, E., TETT, S. F. B., CASTY, C., WANNER, H., 
2006. European climate response to tropical volcanic eruptions over the last half millennium. Geophysical Research Letters, 34, L05707.

FLEITMANN, D., BURNS, S. J., MUDELSEE, M., NEFF, U., KRAMERS, J., MANGINI, A., MATTER, A. (2003): Holocene forcing of the Indian monsoon recorded in a stalagmite from Southern Oman. Science, 300, pp. 1737-1739.

GASSE, F. (2000): Hydrological changes in the African tropics since the Last Glacial Maximum. Quaternary Science Reviews 19, pp. 189-211.

GROVE, J. M. (1988): The Little Ice Age. Routledge, London and New York.

GUPTA, A. K., ANDERSON, D. M., OVERPECK, J. T. (2003): Abrupt changes in the Asian southwest monsoon during the Holocene and their links to the North Atlantic Ocean. Nature, 421, pp. 354-357.

GUPTA, A. K., DAS, M., ANDERSON, D. M. (2005): Solar influence on the Indian summer monsoon during the Holocene. Geophysical Research Letters, 32, doi:10.1029/2005GL022685.

HALL, I. R., BIANCHI, G. G., EVANS, J. R. (2004): Centennial to millennial scale Holocene climate-deep water linkage in the North Atlantic. Quaternary Science Reviews, 23, pp. 1529-1536.

HONG, Y. T., HONG, B., LIN, Q. H., ZHU, Y. X., SHIBATA, Y., MIROTA, M., UCHIDA, M., LENG, X. T., JIANG, H. B., XU, H., WANG, H., YI, L. (2003): Correlation between Indian Ocean summer monsoon and North Atlantic climate during the Holocene. Earth and Planetary Science Letters, 211, pp. 371-380.

HU, F. S., KAUFMANN, D., YONEJI, S., NELSON, D., SHEMESH, A., HUANG, Y., TIAN, J., BOND, G., CLEGG, B., BROWN, T. (2003): Cyclic variation and solar forcing of Holocene climate in the Alaskan Subarctic. Science, 301, pp. 1890-1893.

JENNINGS, A. E., KNUDSEN, K. L., HALD, M., HANSEN, C. V., ANDREWS, J.T. (2002): A mid-Holocene shift in Arctic sea-ice variability on the East Greenland Shelf. The Holocene, 12 , pp. 49-58.

KEELING, C. D., WHORF, T. P. (1997): Possible forcing of global temperature by the oceanic tides. PNAS 94, 8321-8328.

KIRKBY, J. (2008): Cosmic rays and climate. Surveys in Geophysics, 28, pp. 333-375.

LAMY, F., ARZ, H. W., BOND, G. C., BAHR, A., PÄTZOLD, J. (2006): Multicentennialscale hydrological changes in the Black Sea and northern Red Sea during the Holocene and the Arctic/North Atlantic Oscillation. Paleoceanography, 21, PA1008.

LI, Y.-X., YU, Z., KODAMA, K. (2007): Sensitive moisture response to Holocene millennialscale climate variations in the Mid-Atlantic region, USA. The Holocene, 17, pp. 3-8.

MANGINI, A., VERDES, P., SPÖTL, C., SCHOLZ, D., VOLLWEILER, N., KROMER, B. (2007): Persistent influence of the North Atlantic hydrography on central European winter temperature during the last 9000 years. Geophysical Research Letters, 34, L02704,doi:10.1029/2006GL028600.

MARCHAL, O., CACHO, I., STOCKER, T. F., GRIMALT, J. O., CALVO, E., MARTRAT, B., SHACKLETON, N., VAUTRAVERS, M., CORTIJO, E., VAN KREVELD, S., ANDERSSON, C., KOC, N., CHAPMAN, M., SBAFFI, L., DUPLESSY, J.-C., SARNTHEIM, M., TURON, J.-L., DUPRAT, J., JANSEN, E. (2002): Apparent long-term cooling of the sea surface in the northeast Atlantic and Mediterranean during the Holocene. Quaternary Science Reviews, 21, pp. 455-483.

MAYEWSKI, P. A., ROHLING, E. E., STAGER, J. C., KARLEN, W., MAASCH, K. A., MEEKER, L. D., MEYERSON, E. A., GASSE, F., VAN KREFELD, S., HOLMGREN, K., LEE-THORP, J., ROSQVIST, G., RACK, F., STAUBWASSER, M., SCHNEIDER, R. R., STEIG, E.J. (2004): Holocene climate variability. Quaternary Research, 62, pp. 243-255.

MOROS, M., ANREWS, J. T., EBERL, D. D., JANSEN, E. (2006): Holocene history of drift ice in the Northern North Atlantic: Evidence for different spatial and temporal modes. Paleoceanography, 21, doi:10.1029/2005PA001214.

NESJE, A., DAHL, S. O. (1993): Lateglacial and Holocene glacier fluctuations and climate variations in western Norway: a review. Quaternary Science Reviews, 12, pp. 255-261.

NIGGEMANN, S., MANGINI, A., MUDELSEE, M., RICHTER, D. K., WURTH, G. (2003): Sub-Milankovitch climatic cycles in Holocene stalagmites from Sauerland, Germany. Earth and Planetary Science Letters, 216, pp. 539-547.

O'BRIEN, S. R., MAYEWSKI, P. A., MEEKER, L. D., MEESE, D. A., TWICKLER, M. S., WHITLOW, S. I., (1995): Complexitiy of Holocene climate as reconstructed from a Greenland ice core. Science, 270, pp. 1962-1964.

OPPO, D. W., McMANUS, J. F., CULLEN, J. L. (2003): Deepwater variability in the 
Holocene epoch. Nature, 422, pp. 277-278.

PAUL, A., SCHULZ, M. (2002): Holocene climate variability on centennial-to-millennial time scales: 2. Internal and forced oscillations as possible causes. In: Wefer, G. et al. (eds.): Climate development and history of the North Atlantic realm. Springer, Berlin, pp. 55-73.

RENSSEN, H., GOOSSE, H., FICHEFET, T. (2002): Modeling the effect of freshwater pulses on the early Holocene climate variability. Paleoceanography, 17, doi:10.1029/2001/PA000649.

RENSSEN, H., GOOSSE, H., MUSCHELER, R. (2006): Coupled climate model simulation of Holocene cooling events: oceanic feedback amplifies solar forcing. Climate of the Past, 2, pp. 79-90.

RISEBROBAKKEN, B., JANSEN, E., ANDERSSON, C., MJELDE, E., HEVROY, K. (2003): A high-resolution study of Holocene paleoclimatic and paleoceanographic changes in the Nordic Seas. Paleoceanography, 18, pp. 17/1-17/11.

ROBOCK, A., (2000): Volcanic eruptions and climate. Reviews of Geophysics, 38, pp. 191-219.

RUSSELL, J. M., JOHNSON, T. C. (2005): Late Holocene climate change in the North Atlantic and equatorial Africa: Millennial-scale ITCZ migration. Geophysical Research Letters 32, L17705.

SCHULZ, M., PAUL, A. (2002): Holocene climate variability on centennial-to-millennial time scales: 1 Climate records from the North-Atlantic realm. In: Wefer, G. et al. (eds.): Climate development and history of the North Atlantic realm. Springer, Berlin, pp. 41-54.

SCHULZ, M., PRANGE, M., KLOCKER, A., (2007): Low-frequency oscillations of the Atlantic Ocean meridional overturning circulation in a coupled climate model. Climate of the Past, 3, pp. 97-107.

TINSLEY, B. A., BURNS, G. B., ZHOU, L. (2007): The role of the global electric circuit in solar and internal forcing of clouds and climate. Advances in Space Research, 40, pp. 1126-1139.

TURNEY, C., BAILlIE, M., CLEMENS, S., BROWN, D., PALMER, J., PILCHER, J., REIMER, P., LEUSCHNER, H.H. (2005): Testing solar forcing of pervasive Holocene climate cycles. Journal of Quaternary Science, 20, pp. 511-518.

VIAU, A. E., GAJEWSKI, K., SAWADA, M. C., FINES, P. (2006): Millennial-scale temperature variations in North America during the Holocene. Journal of Geophysical Research, 111, doi:10.1029/2005JD006031.

WANG, Y., CHENG, H., EDWARDS, R.L., HE, Y., KONG, X., AN, Z., WU, J., KELLY, M. J., DYKOSKI, C. A., LI, X. (2005): The Holocene Asian monsoon: Links to solar changes and North Atlantic climate. Science, 308, pp. 854-857.

WANNER, H., BEER, J., BÜTIKOFER, J., CROWLEY, T. J., CUBASCH, U., FLÜCKIGER, J., GOOSSE, H., GROSJEAN, M., JOOS, F., KAPLAN, J. O., KÜTTEL, M., MÜLLER, S., PRENTICE, I. C.,SOLOMINA, O., STOCKER, T. F., TARASOV, P., WAGNER, M., WIDMANN, M. (2008): Mid- to late Holocene climate change - an overview. Quaternary Science Reviews, pp. 1791-1828.

WILLARD, D. A., BERNHARDT, C. E., KOREJWO, D. A., MEYERS, S. R. (2005): Impact of millennial-scale Holocene climate variability on eastern North American terrestrial ecosystems: pollen-based climatic reconstruction. Global and Planetary Change, 47, pp. 17-35.

WRIGHT, H. E., KUTZBACH, J. E., WEBB, T. III, RUDDIMAN, W. F., STREET-PERROT, E. A., BARTLEIN, P. J. (eds., 1993): Global Climates since the Last Glacial Maximum. University of Minnesota Press, Minneapolis.

WUNSCH, C. (2000): On sharp spectral lines in the climate record and the millennial peak. Paleoceanography, 15, No. 4, pp. 417-424.

YU, Y., YANG, T., LI, J., LIU, J., AN, C., LIU, X., FAN, Z., LU, Z., LI, Y., SU, X. (2006): Millennial-scale Holocene climate variability in the NW China drylands and links to the tropical Pacific and the North Atlantic. Palaeogeography, Palaeoclimatology, Palaeoecology, 233, pp. 149-162.

YU, Z., CAMPBELL, I. D., CAMPBELL, C., VITT, D. H., BOND, G. C., APPS, M. J. (2003): Carbon sequestration in western Canadian wet-dry climate cycles at millennial scales. The Holocene, 13, pp. 801-808. 


\section{BONDOVY HOLOCÉNNÍ CYKLY: JSOU SKUTEČNÉ NEBO FIKTIVNÍ?}

Na základě analýzy petrologických indikátorů z ledových ker v severním Atlantiku dokázali Bond et al. (1997, 2001), že během holocénu, tedy během posledních 12000 let, došlo k devíti chladným obdobím. Autoři předpokládají, že tyto jevy jsou holocenními ekvivalenty pleistocénních Dansgaard-Oeschgerových cyklů a že se objevují s určitou pravidelností s délkou cyklu cca 1500 let. Na základě literatury (tab. 1), jakož i na základě rozšířené spektrální analýzy různých proxy řad jsme ukázali, že existence takovýchto cyklů se předpokládá v mnoha oblastech světa, ale že neexistují jasné důkazy o cyklech trvajících 1500 let. Jednotliví autoři tedy předpokládají řadu různých spouštěcích mechanismů (napřr. minimální sluneční aktivita, shluky silných tropických sopečných erupcí, zpětné vazby mezi termohalinní cirkulací a dynamikou arktického mořského ledu).

Domníváme se, že Bondův cyklus byl pozorován zejména $\mathrm{v}$ severním Atlantiku a v přilehlých oblastech (východ Spojených států, severní Afrika, Evropa a části Asie). Protože se hraniční podmínky (jako je rozsah kontinentálního zalednění, rozložení mořského ledu, množství tepla $\mathrm{v}$ oceánech, rozložení vegetace) během holocénu výrazně změnily, zastáváme na základě dostupných modelových studií hypotézu, že vznik těchto chladných období byl způsoben různými procesy. Soubor jevů ranného holocénu, jako mladší dryas či 8200 let trvající chladné období, byl vyvolán spíše vodou z tající ledové pokrývky severních kontinentů. Chladná období pozdního holocénu (Bondovy jevy 0,1 a 2 na obr. 1) byla zpo̊sobena spíše součinností různých faktorů, jako omezeného slunečního záření, souběhu několika tropických sopečných výbuchů, posílení studené arktické anticyklony a jejich interakce s dynamikou mořského ledu a termohalinní cirkulací. V průběhu přechodného období před 7 000-4 500 let byly podmínky velice složité, takže jsou potřeba nové údaje a modelové studie. Konečně bychom neměli zapomínat, že důležitou úlohu může hrát vnitřní variabilita systému (tedy kolísání severoatlantské oscilace) a že pro klimatické záznamy je typický spíše široký pás kvaziperiodické variability než jakýkoliv druh významného spektrálního vrcholu.

Obr. 1 - Holocenní záznamy z ledových ker jako percentuální variace petrologických indikátorů. Horní panel: hematitem obalená zrna v \% ve dvou jádrech ze stejné lokality. Spodní panel: soubor čtyř záznamů z různých lokalit. Podle Bonda et al. 1999, pozměněno.

Obr. 2 - Přehled spektrálního chování časových řad analyzovaných Bütikoferem (2007; otevřené kroužky) či řady spektrálních vrcholů uváděných v literatuře (odkazy viz Wanner et al. 2008; černé tečky). Vodorovné čáry představují široké vrcholy. Osa $\mathrm{x}$ vyjadřuje časové měřítko různých vrcholů, osa y ukazuje příslušnou zeměpisnou šířku nepřímých (proxy) dat.

Obr. 3 - Množství všech významných spektrálních vrcholů $\mathrm{v}$ časových řadách znázorněných na obrázku 2. Tmavě šedé sloupky označují zjevné, avšak nikoliv významně vyšší frekvence.

Obr. 4 - Možný mechanismus vzniku studeného období v pozdním holocénu (např. malé doby ledové), kdy došlo $\mathrm{k}$ souběhu letního orbitálního působení na severní polokouli $\mathrm{s}$ nízkou sluneční aktivitou a řadou silných vulkanických erupcí. V obrázku shora: redukovaný Milankovič (orbitální záření), redukované sluneční záření, souběh několika sopečných výbuchů; snížení teploty mořského povrchu v severních oblastech velkých severních kontinentů a posílení polární anticyklony (zejména v zimě); nárůst arktického mořského ledu; omezená hloubková konvekce v severní části Atlantského oceánu.

Authors are with University of Bern, Institute of Geography and Oeschger Centre for Climate Change Research, Hallerstrasse 12, CH-3012 Bern, Switzerland; e-mail: wanner@giub.unibe.ch. 